\title{
X-Ray Diffraction Is a Promising Tool to Characterize Coral Skeletons
}

\author{
M. Azizur Rahman ${ }^{1^{*}}$, Jochen Halfar ${ }^{1}$, Ryuichi Shinjo ${ }^{2}$ \\ ${ }^{1}$ Department of Chemical and Physical Sciences, University of Toronto, Canada \\ ${ }^{2}$ Department of Physics and Earth Sciences, University of the Ryukyus, Okinawa, Japan \\ Email: *mazizur.rahman@utoronto.ca, azizur31@yahoo.com
}

Received March 11, 2013; revised April 12, 2013; accepted April 20, 2013

Copyright (C) 2013 M. Azizur Rahman et al. This is an open access article distributed under the Creative Commons Attribution License, which permits unrestricted use, distribution, and reproduction in any medium, provided the original work is properly cited.

\begin{abstract}
The skeletons of corals are made of calcium carbonate by biomineralization process, in the form of aragonite or calcite. To understand the characteristics of coral skeletons, especially mineralogy, crystal phases, organization and structure in individual species, X-ray powder diffraction techniques have gained increased interest in recent years as useful non-destructive tools. This review provides an overview on the recent progress in this field and briefly introduces the related experimental approach. The application of X-ray diffraction (XRD) to elucidating the structural and mechanical properties of mineral crystals in corals is reviewed in terms of characterization of $\mathrm{CaCO}_{3}$ crystal orientation. In addition, we discuss how this technique has increased our understanding of the function of the organic matrix proteins of calcified coral skeletons during mineral formation. Such information is helpful in deducing the mechanical and structural model of corals with respect to biomineralization system of skeletons.
\end{abstract}

Keywords: Biomineralization; Coral Skeletons; Organic Matrix Proteins; Sclerites; Soft Corals; X-Ray Diffraction

\section{Introduction}

One of the most important events in animal evolution has been the development of a hard skeleton within many independent stocks. In the subsequent diversification of these lines, skeletons have been adapted to fulfill a wide variety of functions, based on tissue support, protection, and locomotion. Skeletons or parts thereof may be variously classified into more or less distinct categories on the basis of position with respect to soft parts (exoskeleton versus endoskeleton), composition (organic versus inorganic, agglutinated versus precipitated, etc.), and permanence. Although the mechanism by which the skeleton forms is unclear, the coral probably removes calcium directly from sea water and combines it with inorganic carbon, consisting of carbon dioxide from respiration and bicarbonate from sea water [1]. It is reported that coral skeletons are composed of calcium carbonate (aragonite or calcite) in an organic matrix [1-8]. The organic matrix is formed prior to mineralization, and it has been suggested that some components of the matrix protein may serve as a template for mineral deposition $[9,10]$.

${ }^{*}$ Corresponding author.
Recent reports have focused on the characterization of proteins in the soluble matrix of soft coral sclerites (endoskeletons) [1,3-6,11-14] and stony corals [2]. The control of the morphology and the chemical composition of calcitic bio-crystals in some precious corals have been reported [15]. Compared to the information available on molluscans, stony corals, calcareous algae, and other skeletal formation [2,16-19], very little is known regarding skeletal characterization of soft corals. In order to characteristics of both skeletons from scleractinian (axial skeletons) and soft coral (endoskeletons), especially mineralogy, crystal phases, organization and structure in individual species need to be investigated by XRD. Surprisingly, this techniques has gained increased interest in recent years as useful non-destructive tools for investigating the structural characterization of calcifying animals $[1$, $3,9,12,14]$. Thus, this technique could be one of the promising tools to understand skeletal components and structural details in corals. This review provides an overview on the recent progress in this field and briefly introduces the related experimental approach. The application of Xray diffraction to elucidating the structural and mechaniccal properties of mineral crystals in coral is reviewed in terms of characterization of $\mathrm{CaCO}_{3}$ crystal orientation. 


\section{Application of X-Ray Diffraction}

$\mathrm{X}$-ray diffraction (XRD) is an effective method for determination of the phase composition of unknown crystalline and amorphous materials. The scattering of X-rays by crystal atoms, produce a diffraction pattern that yields information about the structure of the crystal. This data is represented in a collection of single-phase X-ray powder diffraction patterns for the three most intense $\mathrm{D}$ values in the form of tables of interplanar spacings (D), relative intensities $\left(\mathrm{I} / \mathrm{I}_{\mathrm{o}}\right)$, and mineral name. The techniques of $\mathrm{X}$-ray diffraction analysis are used to study, for example, metals, alloys, minerals, inorganic and organic compounds, polymers, amorphous materials, liquids, gases, and the molecules of proteins and nucleic acids [1,20-26].

As we mentioned above, X-ray powder diffraction analysis could one of the most powerful tools in order to identify the crystal structure and mineral phases in the bio-mineralized protein induced coral skeletons. Crystallization plays a key role in the bio-calcification process and ultimately in the growth of coral skeletons $[1,27]$. Skeletal architecture and microstructure of the calcifying corals were characterized using XRD [27]. Very recently, our group $[3,28]$ identified the polymorphs of calcium carbonate in the soft coral endoskeletons using X-ray diffractional analysis. This XRD technique was used to verify mineral phase in calcified endoskeletons before protein isolation. The XRD pattern of endoskeletons is shown in Figure 1 [28]. The diffraction intensity is the calcite (104) $2 \theta=29.8^{\circ}$ and the next to strongest are the calcites at $\{113\},\{116\}\{018\}\{202\},\{110\},\{012\}$ $\{1010\}$ and $\{215\}$, respectively. The X-ray diffractional analysis revealed that the crystalline form of calcium carbonate in the sclerites was calcitic polycrystals. The diffraction angle, $2 \theta=29.8^{\circ}$ in the calcite (104) indicates $\mathrm{Mg}$-calcite because the diffraction angle for pure calcite is $2 \theta=29.3^{\circ}$ [29]. Beside the identification of mineral and crystals phases, XRD also potential to identify chitin, collagen and strontianite in the coral skeletons [24,25]. Chitin has been identified in the axial skeleton of several species of antipatharian corals by X-ray fiber diffraction patterns. There are reflections in the fiber pattern of the intact skeleton of a lattice, presumably due to protein, with a periodicity of approx $40 \AA$. Hydrolysis of the intact skeleton in dilute alkali yields an insoluble white residue representing less than $10 \%$ of the total skeletal mass, which gives an X-ray diffraction pattern characteristic of the $\beta$-chitin polymorph [24]. An XRD study of sclera-
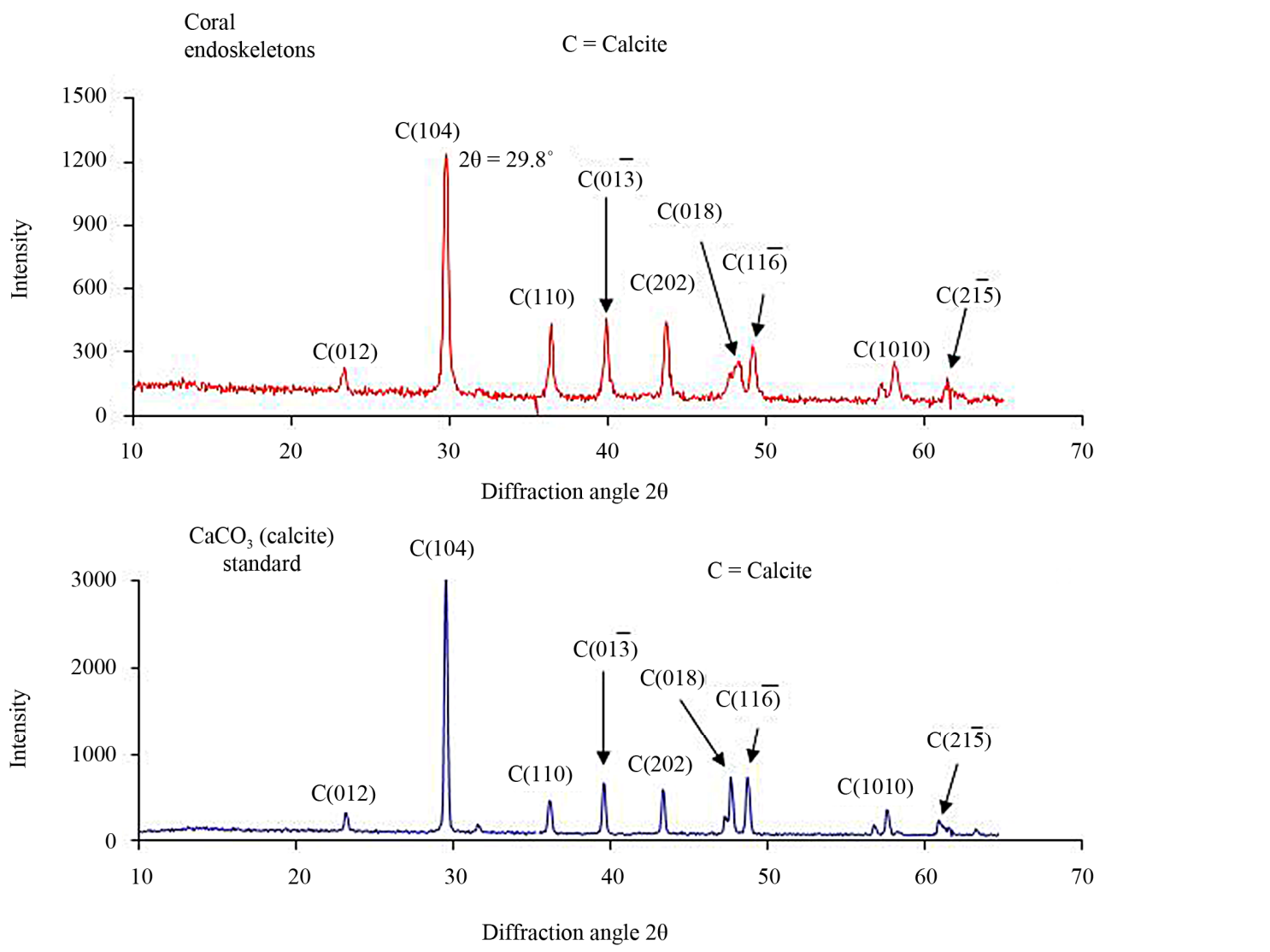

Figure 1. X-ray diffractional analysis of endoskeletons (sclerites). The $2 \theta$ scan identifies the crystalline form of calcium carbonate in the sclerites as calcitic polycrystals. XRD patterns of soft coral's endoskeletons (Top). $\mathrm{CaCO}_{3}$ (calcite) standard (Bottom) [28]. 
actinian coral skeletons indicated that, although some strontium substitutes for calcium in the aragonite structure, at concentrations of about 7500 parts per million, as much as 40 percent of the strontium resides in strontianite $\left(\mathrm{SrCO}_{3}\right)$ [25].

From the last few years $[2,11,12,30]$, acidic proteins were purified from the organic matrices of corals. In the present review, the crystallization of corals in the presence of these proteins was discussed in terms of XRD analysis. One widely used approach for studying the functions of these acidic proteins is to examine their effect on crystal growth, in vitro. Combinations of matrix components have been used to detect a collaborative effect [31], and the ability of demineralized matrix to induce crystal nucleation has been examined [1]. The objective was to understand the principles that govern these interactions and to gain insight into the mechanisms by which these matrix constituents regulate crystal growth in vivo.

The major polymorphisms involved in $\mathrm{CaCO}_{3}$ crystallization of marine organisms were identified and subsequently, the functions of specific organic matrix proteins in the bio-calcification process were determined $[1,3,10$, 14,28,32-37]. Here we showed the polymorphism of crystals in the endoskeletons of a soft coral in presence of matrix proteins by XRD. However, prior to isolate organic matrix proteins from the endoskeletons, there were shown the structural shape and the location of them in the soft coral colony (Figure 2) [3]. Figure 2(B) shows their location in the tentacle. Well-developed spurs are observed on the surface of these endoskeletons (arrows in Figure 2(C)).

How do calcite crystals form in soft corals? Very recently [1], our group have been explored this interesting phenomenon using the promising tool of XRD. A high magnesium/calcium ratio in seawater strongly favors aragonite over calcite precipitation [38,39]. The means by which organisms can precisely control their skeletal mineralogy despite what would be favored by ocean chemistry, however, remained elusive. Using several different approaches, we recently established that the ECMP-67 protein extracted from soft coral sclerites controls the formation of calcite crystals in vitro even when aragonite is favored by the chemistry of the solution from which the crystals are precipitated [1]. In this review, however, we discussed the interesting, as yet uncharacterized phenomenon of how calcite crystals form in soft corals, and the XRD was discussed as the most potential technique to explore this finding. To further study the role of ECMP-67 in mineral formation, in vitro crystallization experiments were conducted with both calcitic and aragonitic solutions [1]. In this report, the influence of $\mathrm{Mg}^{2+}$ on $\mathrm{CaCO}_{3}$ polymorphism was studied. In the absence of both $\mathrm{Mg}^{2+}$ and protein, typical rhombohedral calcite crystals were generated. In the presence $\mathrm{Mg}^{2+}$ but without any protein, large needle-like aragonite crystals were formed. It is interesting that when the solution was supplemented with ECMP-67, all of the crystals formed were calcite instead of aragonite (Figures 3(D)-(G)). Figures 3(D)-(G) show the SEM images of $\mathrm{CaCO}_{3}$ crystals grown in the presence of ECMP-67 at concentrations of 0.7 and $1.4 \mu \mathrm{g} / \mathrm{ml}$. At a concentration of $0.7 \mu \mathrm{g} / \mathrm{ml}$, a number of needle-like aragonite crystals remained (Figures 3(A), arrow, and (B)), and some rhombohedral and round calcite crystals formed (Figures 3(A), arrowhead, and (C)). Both crystallization mineral phases were confirmed by XRD (Figure 3(H)). When ECMP-67 was present at a higher concentration $(1.4 \mu \mathrm{g} / \mathrm{ml})$, the calcite crystals (Figures 3(D)-(G)) formed different shapes, and no aragonite was observed. Although crystal growth was inhibited at high protein concentrations, all of the remaining aragonites formed by $\mathrm{Mg}^{2+}(50 \mathrm{mM})$ were transformed into calcites (Figure 3(D), enlarged view indi-
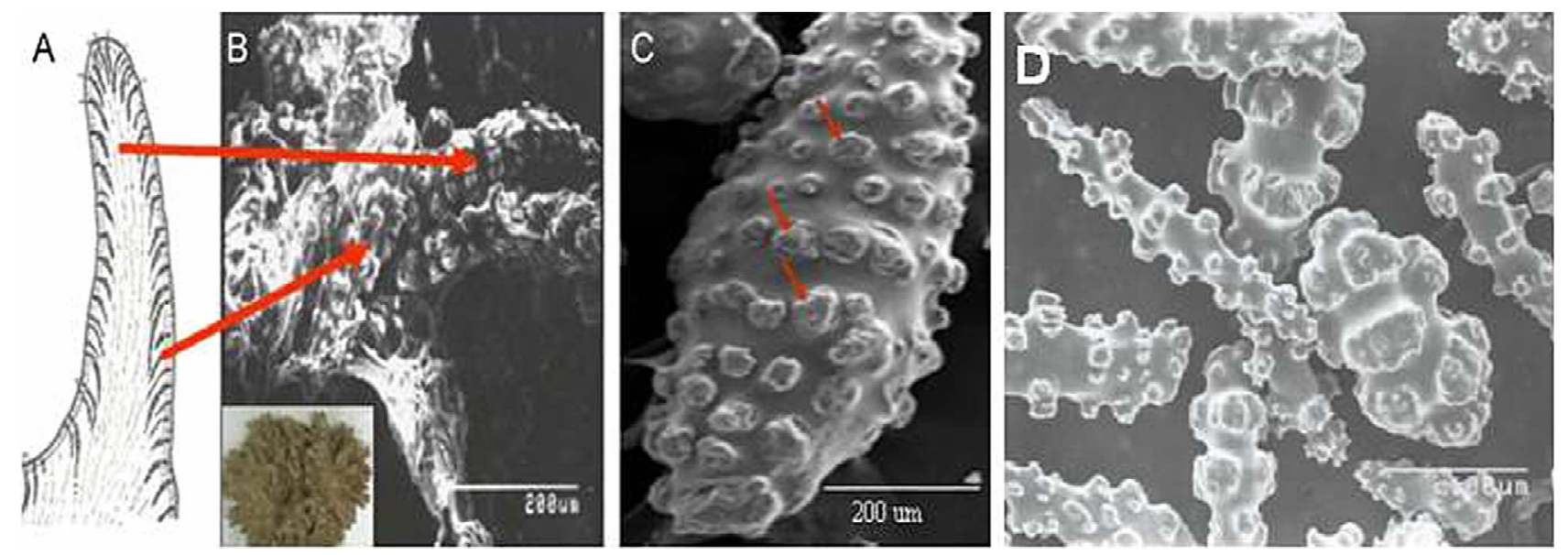

Figure 2. Observation of endoskeletons (sclerites). (A) Computer-drawn tentacle that shows the sclerites inside; (B) SEM of the location of sclerites inside the tentacle. The inset shows the top view of a young colony; (C) SEM of a mature sclerite with well-developed "spurs" (arrows) [3]; (D) Sclerites isolated from the soft coral, Lobophytum crassum. 

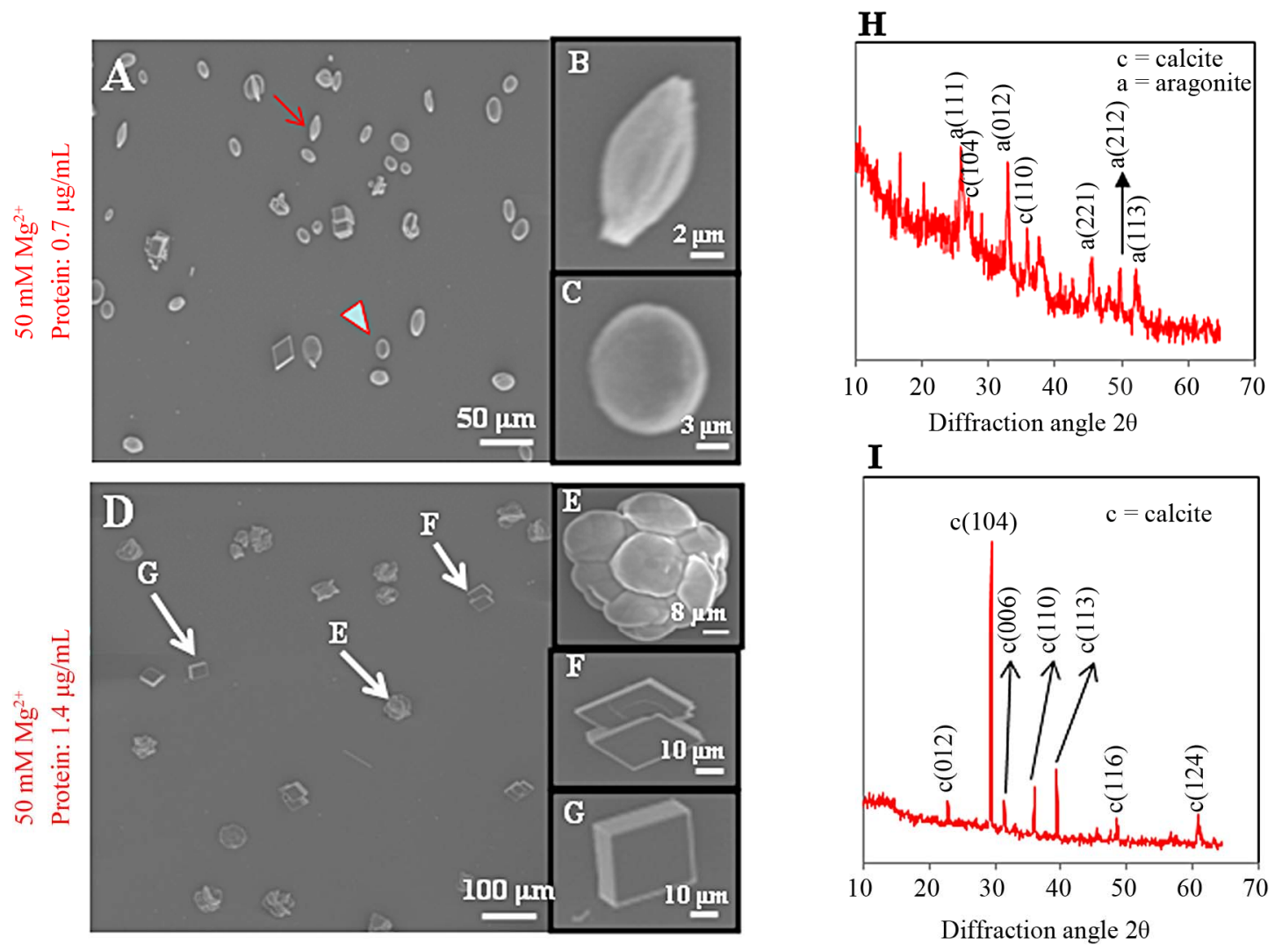

Fiure 3. SEM images of crystals grown in vitro and identification of their polymorphisms by XRD. (A-C) crystals grown in the presence of protein $(0.7 \mu \mathrm{g} / \mathrm{ml})$ and $\mathrm{Mg}^{2+}(50 \mathrm{mM}) ;(\mathrm{D}-\mathrm{G})$ crystals grown in the presence of protein $\left(1.4 \mu \mathrm{g} / \mathrm{ml}^{2}\right)$ and $\mathrm{Mg}^{2+}$ $(50 \mathrm{mM})$; (H, I) verification of the crystal polymorphisms formed in these experiments by XRD. The $2 \theta$ scan diffraction angle identifies the calcite and aragonite minerals shown in SEM panels $A$ and $D$ [1].

cated by arrows in $(\mathbf{E}),(\mathbf{F})$ and $(\mathbf{G}))$. The transition of minerals from aragonites to calcites was confirmed by $\mathrm{XRD}$, which showed that all phases of the crystals were calcites and that no aragonites were present (Figure 3(I)). These results demonstrate the regulation of crystal growth by protein in a $\mathrm{CaCO}_{3}$ system in alcyonarian corals, specifically the inhibition of crystal growth. This study concurred with the similar works recently conducted by Takeuchi and coworkers $[32,37]$.

As we observed, soft corals have special characters because the organic matrices themselves are highly aspartic acid-rich proteins [11,28]. In addition, previous studies on molluscan shells indicate that acidic amino acid residues may actually inhibit crystal nucleation [40]. The present review reveals that organic matrices fractions of some marine organisms were enriched in aspartic acid proteins $[12,32,34]$; the especially high aspartic acid content of insoluble organic matrix proteins may regulate the crystal growth and morphology [4,13,37], or could play a key role in crystal nucleation induction [41-44].

\section{Concluding Remarks}

The information from the basic structural unit of coral skeleton, i.e. mineral-crystal phases in which the organic matrix proteins are primarily responsible for the control of $\mathrm{CaCO}_{3}$ polymorphisms would provide a better understanding of the bulk composition and fragility of the tissue in the crystallization process. In this regard, X-ray diffraction has proved to be an effective technique to examine the structural and mechanical characteristic of coral mineral and provide reliable experimental data. This technique is highly potential in understanding the function of the acidic proteins in the matrices of calcified coral skeletons during biomineralization. This knowledge provides a way to expedite the coral formation and biocalcification processes. Furthermore, the idea about mineral crystals and their organization helps understand the structural integrity in coral and the overall skeletal characteristics. There is still a lot to be achieved; however, recent progress in this field has provided new hopes for future diffraction studies to be used as an effective nondestructive technique and reveal new aspects in the formation of $\mathrm{CaCO}_{3}$ in coral skeletons.

\section{REFERENCES}

[1] M. A. Rahman, et al., "Calcite Formation in Soft Coral 
Sclerites Is Determined by a Single Reactive Extracellular Protein," Journal of Biological Chemistry, Vol. 286, No. 36, 2011, pp. 31638-31649. doi:10.1074/jbc.M109.070185

[2] T. Watanabe, et al., "Molecular Analyses of Protein Components of the Organic Matrix in the Exoskeleton of Two Scleractinian Coral Species," Comparative Biochemistry and Physiology Part B: Biochemistry and Molecular Biology, Vol. 136, No. 4, 2003, pp. 767-774. doi:10.1016/S1096-4959(03)00177-5

[3] M. A. Rahman and T. Oomori, "Structure, Crystallization and Mineral Composition of Sclerites in the Alcyonarian Coral," Journal of Crystal Growth, Vol. 310, No. 15, 2008, pp. 3528-3534. doi:10.1016/j.jcrysgro.2008.04.056

[4] M. A. Rahman, et al., "Analysis of Proteinaceous Components of the Organic Matrix of Endoskeletal Sclerites from the Alcyonarian Lobophytum crassum," Calcified Tissue International, Vol. 78, No. 3, 2006, pp. 178-185. doi:10.1007/s00223-005-0253-y

[5] M. A. Rahman and Y. Isa, "Characterization of Proteins from the Matrix of Spicules from the Alcyonarian, Lobophytum crassum," Journal of Experimental Marine Biology and Ecology, Vol. 321, No. 2, 2005, pp. 71-82. doi:10.1016/j.jembe.2005.01.012

[6] M. A. Rahman, et al., "Proteins of Calcified Endoskeleton: II Partial Amino Acid Sequences of Endoskeletal Proteins and the Characterization of Proteinaceous Organic Matrix of Spicules from the Alcyonarian, Synularia polydactyla," Proteomics, Vol. 5, No. 4, 2005, pp. 885893. doi:10.1002/pmic. 200401130

[7] M. A. Rahman and T. Oomori, "Identification and Function of New Proteins in Calcified Endoskeleton: A New Insight in the Calcification Mechanism of Soft Corals," Oceans, Vol. 1-4, 2008, pp. 2139-2145.

[8] I. Fukuda, et al., "Molecular Cloning of a cDNA Encoding a Soluble Protein in the Coral Exoskeleton," Biochemical and Biophysical Research Communications, Vol. 304, No. 1, 2003, pp. 11-17. doi:10.1016/S0006-291X(03)00527-8

[9] S. M. A. D'Souza, C. Carr, S. W. Waller, A. M. Whitcombe and M. J. Vulfson, "Directed Nucleation of Calcite at a Crystal-Imprinted Polymer Surface," Nature, Vol. 319, 1999, pp. 312-316.

[10] S. Weiner and L. Hood, "Soluble-Protein of Organic Matrix of Mollusk Shells: Potential Template for Shell Formation," Science, Vol. 190, No. 4218, 1975, pp. 987-988. doi:10.1126/science.1188379

[11] M. A. Rahman and T. Oomori, "Analysis of Protein-Induced Calcium Carbonate Crystals in Soft Coral by NearField IR Microspectroscopy," Analytical Sciences, Vol. 25, No. 2, 2009, pp. 153-155. doi:10.2116/analsci.25.153

[12] M. A. Rahman and T. Oomori, "In Vitro Regulation of $\mathrm{CaCO}_{3}$ Crystal Growth by the Highly Acidic Proteins of Calcitic Sclerites in Soft Coral, Sinularia polydactyla," Connective Tissue Research, Vol. 50, No. 5, 2009, pp. 285-293.

[13] M. A. Rahman and T. Oomori, "Aspartic Acid-Rich Proteins in Insoluble Organic Matrix Play a Key Role in the Growth of Calcitic Sclerites in Alcyonarian Coral," Chi- nese Journal of Biotechnology, Vol. 24, 2008, pp. $2127-$ 2128.

[14] M. A. Rahman, et al., "Extracellular Matrix Protein in Calcified Endoskeleton: A Potential Additive for Crystal Growth and Design," Journal of Crystal Growth, Vol. 324 , No. 1, 2011, pp. 177-183. doi:10.1016/j.jcrysgro.2011.03.021

[15] Y. Dauphin, "Mineralizing Matrices in the Skeletal Axes of Two Corallium Species (Alcyonacea)," Comparative Biochemistry and Physiology Part A: Molecular \& Integrative Physiology, Vol. 145, No. 1, 2006, pp. 54-64. doi:10.1016/j.cbpa.2006.04.029

[16] H. Miyamoto, et al., "A Carbonic Anhydrase from the Nacreous Layer in Oyster Pearls," Proceedings of the National Academy of Sciences of USA, Vol. 93, No. 18, 1996, pp. 9657-9660.

[17] A. Linde, et al., "Mineral Induction by Immobilized Polyanionic Proteins," Calcified Tissue International, Vol. 44, No. 4, 1989, pp. 286-295. doi:10.1007/BF02553763

[18] F. Marin, et al., "Screening Molluscan cDNA Expression Libraries with Anti-Shell Matrix Antibodies," Protein Expression and Purification, Vol. 30, No. 2, 2003, pp. 246252. doi:10.1016/S1046-5928(03)00105-0

[19] G. Falini, et al., "Control of Aragonite or Calcite Polymorphism by Mollusk Shell Macromolecules," Science, Vol. 271, No. 5245, 1996, pp. 67-69. doi:10.1126/science.271.5245.67

[20] D. G. Rancourt and M.-Z. Dang, “Absolute Quantification by Powder X-Ray Diffraction of Complex Mixtures of Crystalline and Amorphous Phases for Applications in the Earth Sciences," American Mineralogist, Vol. 90 , No. 10, 2005, pp. 1571-1586. doi:10.2138/am.2005.1794

[21] S. M. D'Souza, et al., "Directed Nucleation of Calcite at a Crystal-Imprinted Polymer Surface," Nature, Vol. 398, No. 6725, 1999, pp. 312-316. doi:10.1038/18636

[22] J. B. Ries, "Skeletal Mineralogy in a High- $\mathrm{CO}_{2}$ World," Journal of Experimental Marine Biology and Ecology, Vol. 403, No. 1-2, 2011, pp. 54-64. doi:10.1016/j.jembe.2011.04.006

[23] J. Titschack, et al., "Magnesium Quantification in Calcites $\left[(\mathrm{Ca}, \mathrm{Mg}) \mathrm{CO}_{3}\right]$ by Rietveld-Based XRD Analysis: Revisiting a Well-Established Method," American Mineralogist, Vol. 96, 2011, pp. 1028-1038. doi:10.2138/am.2011.3665

[24] L. C. Ellis, et al., "X-Ray Diffraction Evidence of Chitin in the Axial Skeleton of Antipatharian Corals," Comparative Biochemistry and Physiology, Vol. 66B, 1980, pp. 163-165.

[25] R. B. Greegor, et al., "Strontianite in Coral Skeletal Aragonite," Science, Vol. 275, 1997, pp. 1452-1454. doi:10.1126/science.275.5305.1452

[26] S. Weiner and L. Addadi, "Sea Urchins as Crystallographers-Response," Science, Vol. 311, No. 5767, 2006, p. 1555 .

[27] D. Dahan, R. Vago and Y. Golan, "Skeletal Architecture and Microstructure of the Calcifying Coral Fungia Simplex," Materials Science and Engineering C, Vol. 23, No. 
4, 2003, pp. 473-477. doi:10.1016/S0928-4931(02)00113-3

[28] M. A. Rahman and T. Oomori, "In Vitro Regulation of $\mathrm{CaCO}_{3}$ Crystal Growth by the Highly Acidic Proteins of Calcitic Sclerites in Soft Coral, Sinularia polydactyla," Connective Tissue Research, Vol. 50, No. 5, 2009, pp. 285-293.

[29] A. M. Belchar, et al., "Control of Crystal Phase Switching and Orientation by Soluble Mollusc-Shell Proteins," Nature, Vol. 381, 1996, pp. 56-58. doi:10.1038/381056a0

[30] M. A. Rahman, et al., "Studies on Two Closely Related Species of Octocorallians: Biochemical and Molecular Characteristics of the Organic Matrices of Endoskeletal Sclerites," Marine Biotechnology, Vol. 8, 2006, pp. 415424. doi:10.1007/s10126-005-6150-6

[31] J. D. Termine, et al., "Osteonectin, a Bone-Specific Protein Linking Mineral to Collagen," Cell, Vol. 26, No. 1, 1981, pp. 99-105. doi:10.1016/0092-8674(81)90037-4

[32] T. Takeuchi, et al., "In Vitro Regulation of $\mathrm{CaCO}_{3}$ Crystal Polymorphism by the Highly Acidic Molluscan Shell Protein Aspein," FEBS Letters, Vol. 582, No. 5, 2008, pp. 591-596. doi:10.1016/j.febslet.2008.01.026

[33] S. Weiner and L. Addadi, "Acidic Macromolecules of Mineralized Tissues: The Controllers of Crystal Formation," Trends in Biochemical Sciences, Vol. 16, 1991, pp. 252-256. doi:10.1016/0968-0004(91)90098-G

[34] S. Weiner, "Aspartic Acid-Rich Proteins: Major Components of the Soluble Organic Matrix of Mollusk Shells," Calcified Tissue International, Vol. 29, No. 1, 1979. pp. 163-167. doi:10.1007/BF02408072

[35] M. A. Rahman and T. Oomori, "Identification and Function of New Proteins in Calcified Endoskeleton: A New Insight in the Calcification Mechanism of Soft Corals," Oceans 2008, Vol. 1-4, 2008, pp. 2139-2145.

[36] M. A. Rahman, et al., "Analysis of the Proteinaceous Components of the Organic Matrix of Calcitic Sclerites from the Soft Coral Sinularia sp.," PLoS ONE, Vol. 8, No. 3, Article ID: e58781. doi:10.1371/journal.pone.0058781

[37] M. Suzuki, et al., "An Acidic Matrix Protein, Pif, Is a Key Macromolecule for Nacre Formation," Science, Vol. 325, No. 5946, 2009, pp. 1388-1390. doi:10.1126/science. 1173793

[38] S. M. Stanley and L. A. Hardie, "Secular Oscillations in the Carbonate Mineralogy of Reef-Building and Sediment-Producing Organisms Driven by Tectonically Forced Shifts in Seawater Chemistry," Palaeogeography Palaeoclimatology Palaeoecology, Vol. 144, No. 1, 1998, pp. 3-19. doi:10.1016/S0031-0182(98)00109-6

[39] K. J. Davis, et al., "The Role of $\mathrm{Mg}^{2+}$ as an Impurity in Calcite Growth," Science, Vol. 290, No. 5494, 2000, pp. 1134-1137. doi:10.1126/science.290.5494.1134

[40] K. M. Wilbur and A. M. Bernhardt, "Mineralization of Molluscan Shell: Effects of Free and Polyamono Acids on Crystal Growth Rate in Vitro," American Zoologist, Vol. 22, No. 4, 1982, p. 952.

[41] L. Addadi, et al., "Mollusk Shell Formation: A Source of New Concepts for Understanding Biomineralization Processes," Chemistry-A European Journal, Vol. 12, No. 4, 2006, pp. 981-987. doi:10.1002/chem.200500980

[42] L. Addadi, et al., "Taking Advantage of Disorder: Amorphous Calcium Carbonate and Its Roles in Biomineralization," Advanced Materials, Vol. 15, No. 12, 2003, pp. 959-970. doi:10.1002/adma.200300381

[43] L. Addadi, et al., "Structural Control over the Formation of Calcium Carbonate Mineral Phases in Biomineralization," Supramolecular Stereochemistry NATO ASI Series, Vol. 473, 1995, pp. 127-139.

[44] L. Addadi, et al., "Structural and Stereochemical Relations between Acidic Macromolecules of Organic Matrices and Crystals," Connective Tissue Research, Vol. 21, No. 1-4, 1989, pp. 127-134. doi: $10.3109 / 03008208909050003$ 